Original Research

\title{
The Impact of "Cards in Pairs" Games to The Elementary Student's Knowledge of Personal Safety Skill for Prevent Sexual Violence in Public Elementary School 2 Serangan
}

Ni Luh Putu Yunianti Suntari ${ }^{1 *}$, Ni Nyoman Hartati ${ }^{1}$, Ida Ayu Rika Kusumadewi ${ }^{1}$, \& Ni Kadek Suliani ${ }^{1}$

${ }^{1}$ Poltekkes Kemenkes Denpasar, Denpasar, Indonesia

\begin{tabular}{|c|c|}
\hline Article Info & Abstract \\
\hline $\begin{array}{l}\text { Article history: } \\
\text { Received: } \\
\text { 21 Desember } 2020\end{array}$ & $\begin{array}{l}\text { Introduction: The purpose of this research is to know the effect of "cards in } \\
\text { pairs" games to the students' knowledge of personal safety skill to prevent } \\
\text { from sexual violence. }\end{array}$ \\
\hline $\begin{array}{l}\text { Accepted: } \\
25 \text { March } 2021\end{array}$ & $\begin{array}{l}\text { Methods: The kind of this research is Pre-Experimental Design with the } \\
\text { layout was One-Group Pretest-Posttest used stratified random sampling, } \\
\text { with } 90 \text { samples. }\end{array}$ \\
\hline $\begin{array}{l}\text { Keywords: } \\
\text { sexual violence, } \\
\text { personal safety skill, } \\
\text { cards in pairs }\end{array}$ & $\begin{array}{l}\text { Results: The result of this research showed that the students' knowledge of } \\
\text { personal safety skill before giving the game mostly in the category enough } \\
\text { that was } 35 \text { people }(38,9 \%) \text { and after giving the game showed that the } \\
\text { knowledge of personal safety skill were increase to the students with the } \\
\text { most results of the students in the category good that was } 69 \text { people } \\
(76,7 \%) \text {. The result of this research tested by Wilcoxon test, the obtained } \\
\text { value p-value }=0,000<\text { alpha }(0,05) \text {, then it could be concluded that there } \\
\text { was impact by giving sexual education and self-protection from sexual } \\
\text { violence with "cards in pairs" games media. } \\
\text { Conclusion: According the result of the research, it is recommended to the } \\
\text { teacher in the school to improve giving the self-protection materials by } \\
\text { applying the media "cards in pairs" game, which has an impact on this } \\
\text { research. }\end{array}$ \\
\hline
\end{tabular}

*Corresponding Author:

e-mail: yuni.suntari@yahoo.com

This work is licensed under a Creative Commons Attribution 4.0 International License. 


\section{INTRODUCTION}

Sexual violence is part of sexual activity that includes physical or non-physical contact that leads to a part of a sexual body or sexuality which can cause the victim to feel uncomfortable, feel humiliated, and capable and it can make health problems to someone's life threatening condition [1].

In the world, 73 million boys and 150 million girls are victims of sexual violence. Some countries noted that around $21 \%$ of women reported having been sexually abused when they were under 15 years old. Half of them were children under the age of 15 years, and 700,000 of them were human trafficking, and $80 \%$ of human trafficking are children and women [1].

Indonesia's prevalence of sexuality violence against children increased $100 \%$ in 2014 from 2013. From 2011 to 2016 there were 1965 cases of sexual crime in Indonesia, 2857 were children online pornography victims, 306 were children commercial sexual violence, 365 were children online prostitution, and 63 were children abortion [2].

Bali is one of susceptible area from sexual victims, it can indicate from Indonesian Child Protection Commission data in 2011 to 201629 children were sexual violence victims, 85 of them is online sexual violence victims, 4 children were online prostitution victims and 7 children were commercial sexual exploitation victims [2].

Bali is a world-famous tourist destination. The other side of tourism in Bali has a negative impact on the lives of Balinese people, especially children, as reported in 2008 victims of sexual violence by pedophile foreigners, around 137 boys and girls became their victims [3].

Sexual violence has a serious impact on victims in terms of their psychology, which can lead to a decrease in self-esteem, reduced self-esteem, anxiety, fear of rape or other crimes. In children symptoms of depression can occur, feelings of helplessness, feeling isolated, irritability, fear, anxiety, until abuse of addictive substances. The physical impact of sexual violence can be a pregnancy disorder due to an unwanted pregnancy which is the effect of rape, sexual or reproductive health disorders can be a sexually transmitted infection, and the risk of injuring yourself to victims of sexual violence. Sexual violence can also have an impact on the social life of the victim in the form of a problem with the victim's culture which makes problem in victims's interaction, the issue of self-esteem where rapists are obliged to marry victims to make amends to maintain the good name of the victim's family [4].

The Effect of sexual violence was very disturbing their victims so sexual violence must be prevented. Some ways to prevent sexual violence with psychological support, strict legal treatment for the perpetrators, skills education of knowledge about sexuality, and development approaches, approach and discussion, adjust children's development according to their stages, such as teaching about gender, and regarding sexual violence, and what good and bad things to do [4].

According to Kendall in Aprilaz (2016) Education about early sex in children can be provided with personal safety skills, namely early sex education given to children about what they can do if there are situations that 
threaten them so they can be in a safe situation. The education of personal safety skills in children can also give children the ability to protect themselves. Efforts to prevent sexual violence can be carried out through skills education in knowledge about sexuality [5].

Early childhood is often said to be the golden age or the Golden Age Moment. Age 0 to 8 years is a period where children have the ability to absorb information very rapidly. Cognitive education about sexuality is very important to give to children of this age to be able to prevent children from misinformation through media [6]

According to Bruner in Asih Mardati (2015), learning media that are developed like picture card games that contain concrete images or in the form of words, students in elementary school age are the beginning of the transition in learning patterns from previous education. Learners more quickly understand the concept that will be delivered by using concrete images. In accordance with one's cognitive development through 3 stages, namely, the iconic stage, the active stage, and the symbolic stage. The use of picture media goes into the iconic stage where the stages of children have grown and can use imagination, images, or icons to understand the world and use it to help children think [7].

Personal safety skills education with the "Cards in Pairs" Game method will be given to children at Public Elementary School 2 Serangan. Based on the preliminary study that the researchers conducted, data was obtained in the form of acts of sexual violence that befell a student of Public Elementary School 2 Serangan that occurred outside of school hours. According to one of the teachers at Public Elementary School 2 Serangan, counseling or education has never been carried out on the protection of children against sexual violence. The study was conducted at Public Elementary School 2 Serangan with a population of students in grades 1, 2, and 3 with a number of populations 118 .

\section{METHODS}

The research design in this study was preexperimental with a one group pre-post test design. The selection of samples from the population uses the stratified random sampling technique. After getting respondents after the inclusion and exclusion criteria, the researchers then measured the personal knowledge of students' safety skills with a questionnaire.

This research has passed an ethical review and obtained an ethical approval number: LB.02.03/EA/KEPK)282/2018 by the Ethical Health Research Commission, Denpasar Health Polytechnic.

This study was conducted at Public Elementary School 2 Serangan on July 24th until September 30th 2018. The data analysis technique used in this study was the Wilcoxon test (with alpha 0.05 or $95 \%$ confidence level). After going through the data collection process, it was found 90 research subjects who met the inclusion requirements.

\section{RESULTS}

Based on the table 1, the results of the study show that the students' personal knowledge of safety skills before playing "Cards in Pairs" Games is the most in the adequate category 
were 48 people (53.5\%), and at least in the less category were 7 people (7.8\%). The results of the study show that students' personal knowledge of safety skills after playing "Cards in Pairs" Games is mostly in the good category, as many as 69 people (76.7\%).

This study uses the Wilcoxon statistical test because the data in this study are nonparametric categorical which have been tested for data normality using the Kolmogorov-smirnov test with the results of the Sig. the pre-test data table is 0.093 and the Sig. in the post test data table 0,000 . Based on the table 3 , it can be seen that the comparison of the pre-test and post-test scores of students after being given "Cards in Pairs" game is 2 people with a smaller post-test score than the pre-test scores, most students experience increased personal safety skills to prevent sexual violence before and after the provision of Card Games, it was seen from the results of the post-test scores that were greater than the pre-test scores of 41 people (45.6\%). The results of this study were tested with the Wilcoxon statistical test and $\rho$-value was obtained in the Sig. $=0,000<$ alpha $(0,05)$ this means that the research hypothesis is accepted which shows the influence of giving a "Cards in Pairs" game can increase personal knowledge of safety skills to prevent sexual violence in Public Elementary School 2 Serangan.

\section{Table 1}

Respondents Frequency Distribution Based on Personal Safety Skills Knowledge of Students Before and After playing "Cards in Pairs" Games at Public Elementary School 2 Serangan in 2018

\begin{tabular}{lcc}
\hline Student's Personal safety skill Knowlegde & Frequency(n) & Percentage \\
\hline Before & & \\
\hline Good & 35 & 38,9 \\
Enough & 48 & 53,5 \\
Less & 7 & 7,9 \\
\hline Total & 90 & 100,0 \\
\hline After & & 76,7 \\
\hline Good & 69 & 22,2 \\
Enough & 20 & 1,1 \\
Less & 1 & 100,0 \\
\hline Total & 90 & \\
\hline
\end{tabular}

Table 2

Results of Analysis of the Effects of "Cards in Pairs" Games on Students' Knowledge of Personal Safety Skills to Prevent Sexual Violence at Public Elementary School 2 Serangan in 2018

\begin{tabular}{lccc}
\hline Post-Pre & Frequency (n) & Percentage (\%) & p-value \\
\hline Post test $<$ Pre test & 2 & 2,2 & \\
Post test $>$ Pre test & 41 & 45,6 & 0,000 \\
Post test $=$ Pre test & 47 & 52,2 & \\
\hline Total & 90 & 100 & \\
\hline
\end{tabular}




\section{DISCUSSION}

The results of this study indicate the value of personal knowledge of student safety skills is still varied, although most students are in the sufficient category but there are still some levels of personal knowledge of safety skills of students who are in the less category. This is because most students do not know yet what to do in the face of the threat of sexual violence, so cognitive education regarding sexuality and self-protection is very important to give to the children of this age to be able to prevent children from misinformation through the media [5].

Based on prior research, the evaluation of sexual violence prevention programs based on personal safety skills teaching showed that school-age children demonstrated increased knowledge and skills in maintain personal safety from acts of sexual violence, the knowledge of students' personal protection can be improved by providing personal safety skills education to students at school. Teaching personal safety skills is good for school-age children because children at this stage are mature enough to use logical thinking, but only physical objects that exist today (because it is called a concrete operational stage). But without physical objects in front of them, children at school are still difficult in completing logical tasks, so that at this age children can receive information well through physical objects such as games [8].

This shows that elementary school-aged children as respondents in this study have been able to receive personal safety skill knowledge about self-protection which contains things that must be done and should not be done by children to protect themselves from the threat of sexual violence provided by researchers through "Cards in Pairs" game media.

The provision of sexual education on personal safety skills with the method of pairing cards in this study was conducted at Public Elementary School 2 Serangan. Researchers chose schools to provide elementary school age children with personal safety skill knowledge. The opinion of researchers is that the school community has a great potential in disseminating knowledge about personal safety skills as preventing sexual violence. During the development of school-age children, namely in the industrial phase, the ability of the child industry tended to increase when given school education by teachers compared to home parents. According to prior research [9], the results showed a significant increase between the development of industrial children before and after getting Therapeutic Group Therapy school children in the intervention group with parents of 77.62 (77.62\%), intervention group with teachers $83.61(83,61 \%)$ so that it increases significantly when compared to groups that do not get Therapeutic Group Therapy.

The results of this study indicate that the personal knowledge of students' safety skills after being given the game is mostly in the very good category, as many as 69 people $(76.7 \%)$ compared to the value before being given a very good game category only (38.9\%).

The above proves that there has been an increase in students' personal knowledge of safety skills after being given a game where 
some children are in a very good category, but $21(23.3 \%)$ students are still in the range of sufficient categories to less categories. The reason for this is that there are still barriers to delivering information to students, where some students are more focused on playing on their own when the researcher presents material through a card. It is expected that school teachers in the provision of personal safety skill material with games are either included in school extracurriculars, or parents at home to deliver personal safety skill material with media that still conditions children's focus on material so that the target personal knowledge of children's safety skills reaches $100 \%$ in good category.

This research is in line with prior research, which show increased results for cognitive, affective and psychomotor before and after the implementation of the program the introduction of social life skills to prevent sexual violence in children by the method of recognizing self-identity in children [10].

"Cards in Pairs" Games in this study were carried out for 30 minutes involving 90 students of class 2.3, and 4 in Public Elementary School 2 Serangan. Giving "Cards in Pairs" games are given per group consisting of 9 students who get a cards, where these children will work together to install a card that is in accordance with the material that has been given regarding body parts that should not be touched. Every child has the opportunity to play in turns using a "Cards in Pairs" and direct their friends to act correctly in determining body parts that can be touched by others. After being given a "Cards in Pairs" game there is an increase in personal knowledge of safety skills according to the results above.

For children, playing is their main activity. In playing, they don't just find pleasure. But also foster a sense of friendship, care, self-confidence. According to researcher, the "Cards in Pairs" game is a fun game. In the activity, the children were challenged to find the matching cards that matched them. The success of matching these cards can foster a sense of satisfaction and self-confidence. Besides that, it is also an excellent educational medium for children, because this game can teach many things. Like getting to know your own limbs. How to feel limbs. Learn to protect limbs. Get to know the body parts that cannot be shown or touched by other people. Providing education by giving a game will make children more quickly receive the material given because usually the provision of education is more often given by the lecture method and question and answer only which makes the child more tired of listening to the material provided.

Based on the results of the Wilcoxon statistical test, the $\rho$-value is obtained in the Sig column. (2-tailed) $=0.0000 \quad(<$ alpha (0.05)) this indicates that there is an effect of giving a "Cards in Pairs" game. This game can improve personal knowledge of students' safety skills to prevent sexual violence at Public Elementary School 2 Serangan. Increased personal knowledge of safety skills before and after the giving "Cards in Pairs" game is seen from the results of the post-test value which is greater than the pre-test value of 41 people (45.6\%). The results of this study indicate that Cards in Pairs" game have the effect of increasing students' personal 
knowledge of safety skills to prevent sexual violence. Although the improvement of good categories is not experienced by all students, or they do not experience improvement, because during practice their concentration is interrupted by other activities, such as joking with friends. But overall this game has increased most of the knowledge of students who were previously in the enough category to be good.

Children ages 7-11 understand logical operations with the help of concrete objects. This ability manifests itself in understanding the concept of eternity, the ability to classify and harmonize, being able to objectively see objects from a different perspective [6].

Based on the results of the research and theory shown, the researchers argue that children aged 7 - 12 years are good to be given the development of personal safety skill materials to prevent sexual violence by giving other methods and more interesting one of them with playing media because children at this age entering a concrete operational period so that they can better understand the material with real media. In addition to "Cards in Pairs" games, there are still other games that might be used as a reference for the media to provide education about personal safety skills that can further enhance selfprotection knowledge from sexual violence in children in elementary schools.

\section{CONCLUSION}

The results of the level of personal knowledge of students' safety skills to prevent sexual violence before being given a "Cards in Pairs" game were the most students in the sufficient category, namely as many as 35 people
(38.9\%), and some were in the good category as many as 48 people (53.3\%) and less category with 7 people $(7.8 \%)$.

Personal knowledge of students' safety skills to prevent sexual violence after being given a "Cards in Pairs" game, most of the students in the good category were 69 people $(76.7 \%)$, and there were those in the adequate category of 20 people $(22.2 \%)$ and less categories with the number of 1 person (1.1\%).

There is the influence of providing secondary education and self-protection with "Cards in Pairs" playing media on students' personal knowledge of safety skills to prevent sexual violence with a $\rho$-value in the column Sig (2-tailed) was 0,000. "Cards in Pairs" game is highly recommended as a learning medium, how to protect oneself from the threat of sexual crimes. It has been shown how the game has largely increased students knowledge of self-protection from sexual crimes.

\section{REFERENCES}

[1] G. Howe, "Sexual Violence Against Children in the Caribbean: Report 2012," Bridgetown, 2013. Accessed: Mar. 24, 2021. [Online]. Available: https://www.unicef.org/ECAO_Sexual_V iolence_againstChildren_in_the_Caribbea n.pdf.

[2] KPAI, "Data Kasus Perlindungan Anak Berdasarkan Lokasi Pengaduan dan Pemantauan Media Se-Indonesia Tahun 2011-2016," 2016.

[3] CASA, "Bali banyak hasilkan korban Pedofil: Committee Against Sexual 
Abuse."

http://www.casabali.org/2008/10/bali

-banyak-hasilkan-korban-pedofil/

(accessed Mar. 24, 2021).

[4] World Health Organization, "WHO South-East Asia Journal of Public Health," Medknow Publications, 2017. [Online]. Available: http://www.whoseajph.org/showBackIssue.asp?issn=22 24-

3151; year=2017; volume=6;issue =1;mo nth=April.

[5] I. Aprilaz, "Perbandingan efektivitas antara metode video dan cerita boneka dalam pendidikan seksual terhadap pengetahuan anak prasekolah tentang personal safety skill," OPAC Pus. Perpust. UIN Syarif Hidayatullah Jakarta, 2016, Accessed: Mar. 24, 2021. [Online]. Available:

https://onesearch.id/Record/IOS3659. 82042/Holdings\#tabnav.

[6] R. L. Collins, V. C. Strasburger, J. D. Brown, E. Donnerstein, A. Lenhart, and L. M. Ward, "Sexual media and childhood well-being and health," Pediatr. Am. Acad. Pediatr., vol. 140, no. 2, pp. 162166, Nov. 2017, doi: 10.1542/peds.20161758X.
[7] A. Mardati and M. N. Wangid, "Pengembangan Media Permainan Kartu Gambar Dengan Teknik 'Make A Match' Untuk Kelas I SD," J. Prima Edukasia, vol. 3, no. 2, pp. 120-132, 2015, [Online]. Available: https://journal.uny.ac.id/index.php/jpe /article/view/6532.

[8] T. Handayani, "Pencegahan Permainan 'STARTER' Melalui Pendekatan Personal Safety Skill Pada Murid Sekolah Dasar," J. Empower., vol. 1, no. 1, pp. 61-72, Jun. 2017, Accessed: Mar. 24, 2021. [Online]. Available: https://jurnal.unsur.ac.id/je/article/vie $\mathrm{w} / 21 / 13$.

[9] D. Istiana, B. Anna Keliat, and T. Nuraini, “Terapi Kelompok Terapeutik Anak Dengan Orang Tua Dan Guru Meningkatkan Perkembangan Mental Anak Usia Sekolah," 2011. doi: 10.20473/JN.V6I1.3971.

[10] K. Qonita, "The Effectiveness Of The 'Me And You' Program Guidelines For Social Life Skills And Sexual Abuse Prevention Efforts In Preschool Children," Int. J. Technol. Enhanc. Emerg. Eng. Res., vol. 3, no. 8, pp. 80-85, 2015, Accessed: Mar. 24, 2021. [Online]. Available: https://issuu.com/ijteee/docs/theeffectiveness-of-the-me-and-you. 